of selective inhibitors. Trends Pharmacol $S c i$ 1990;11:150-5.

42 Giembycz MA. Could isoenzyme selective phosphodiesterase inhibitors render bronchodilator therapy redundant in the treatment of bronchial asthma? Biochem Pharmacol 1992;43:2041-51.

43 Stevens RL, Austen KF. Recent advances in the cellular and molecular biology of mast cells. Immunol Today 1989;10:381-6.

44 Kay AB, Corrigan CJ. Eosinophils and neutrophils. $\mathrm{Br}$ Med Bull 1992;48:51-64.
45 Barnes PJ. Biochemistry of asthma. Trends Biochem Sci 1991;16:365-9.

46 Wagner CD, Gundel RH, Reilly P, Haynes N, Letts LG, Rothlein R. Intercellular adhesion molecule-1 (ICAM1) in the pathogenesis of asthma. Science 1) in the

47 Barnes PJ. New therapeutic approaches. Br Med Bull 1992;48:231-47.

48 Morley J, Sanjar S, Page CP. The platelet in asthma. Lancet 1984;ii:1142-4.

\title{
Adventitia
}

\section{Dusts and lungs}

Following up a nascent interest in occupational and environmental lung diseases during my first few faculty years I embarked on an academic visit to several centres in Britain. It was during the late 1960s, and my "hangouts" (besides the King's Road) were primarily the Brompton, the London School of Hygiene and Tropical Medicine, and the Medical Research Council Pneumoconiosis Unit. Britain was a spectacular place for learning how to investigate occupational lung diseases. Among many leaders in this field were Richard Schilling and Molly Newhouse at Keppel Street and Gower Street, Margaret Turner-Warwick and Jack Pepys on the Fulham Road, and John Gilson and colleagues in Penarth. Since then, happily, there have been many opportunities for return visits and scientific collaboration with overseas colleagues. I have repeatedly gained knowledge and insight from these relationships. Here are two such examples.

About 10 years ago, my colleagues at Tulane and I began a large, multi-mill longitudinal study of cotton textile workers in the South eastern United States. A major objective was to test Richard Schilling's hypothesis that, besides periodic symptoms of byssinosis, cotton textile workers were at risk of chronic progressive airways obstruction. Cumulative dust exposure estimates for each individual were based on air sampling data and job histories. After five years of data collection analyses taking smoking into account and using the individual exposure estimates failed to provide convincing relationships between dust exposure and annual change in lung function. It was time to discuss our difficulties with Richard Schilling on my next visit to Britain. By the time we sat down to talk he had already figured out that we were probably trying to "fine tune" the individual exposure estimates excessively-beyond the realities of the data from mills, where jobs were most often not clearly physically separated. He had calculated that if the average exposure of the mill were assigned to the workers of that mill the dose dependency of the annual change in $\mathrm{FEV}_{1}$ was clearly seen in yarn manufacturing workers, particularly if they smoked. Richard's experience in assessing exposure in an industry that he knew so well allowed us to complete the analyses and interpretation and show the potential for an adverse exposure related effect on the airways (in smoking workers who produced yarn), even at the low levels of exposure now mandated by regulation.

The chest radiograph was recognised as a useful tool in diagnosing pneumoconiosis in the 1930 s, but its role in epidemiology awaited the development and several refinements of a standardised international classification. The resulting system has repeatedly been shown to quantify responses to (and, of course, retention of) mineral dusts and has produced dose-response relationships useful in the setting of workplace standards around the world. No person has contributed more to these methods than John Gilson. In my research unit it was always a special occasion when John was in residence for a fortnight, spending many full days classifying survey films (while Margaret was producing marvellous water colours of industrial scenes along the Mississippi River). On the occasion of John's last visit, however, he was particularly unhappy about the technical quality of the radiographs and the variability of this quality, as they had been obtained from laboratories situated in the different locations of the manmade mineral fibre plants under study. As we drove home each evening his frustration was clear-I, only half jokingly, wondered aloud whether a bad bout of hay fever and its attendant watery eyes, induced by the New Orleans allergenic environment, contributed to John's poor opinion of the film quality!

He was, as usual, absolutely correct, as the analyses showed unexpectedly high interobserver and intraobserver variability of the readings, undoubtedly due to the combination of the variable quality and minimal abnormality. His repeated emphasis on films of uniformly high quality for epidemiological research is to be heeded now more than ever before as investigators survey populations in which abnormalities on the chest film are at the "margin," the central question being "Is there an effect?"

These have been great years, in no small way a consequence of the extraordinary professional guidance that I have received from my British colleagues.

HANS WEILL 